\title{
Tabularia
}

TABULARIA Sources écrites des mondes normands médiévaux

Autour des sagas : manuscrits, transmission et

écriture de l'histoire | 2015

\section{Legendary sagas as historical sources}

Les sagas légendaires en tant que sources historiques

Le saghe leggendarie come fonti storiche

\section{Hans Jacob Orning}

\section{(2) OpenEdition}

\section{Journals}

Electronic version

URL: http://journals.openedition.org/tabularia/2203

DOI: $10.4000 /$ tabularia.2203

ISSN: $1630-7364$

Publisher:

CRAHAM - Centre Michel de Boüard, Presses universitaires de Caen

Electronic reference

Hans Jacob Orning, «Legendary sagas as historical sources », Tabularia [Online], Autour des sagas manuscrits, transmission et écriture de l'histoire, Online since 14 October 2015, connection on 19 April 2019. URL : http://journals.openedition.org/tabularia/2203 ; DOI : 10.4000/tabularia.2203 


\title{
Legendary sagas as historical sources
}

\section{Les sagas légendaires en tant que sources historiques}

\section{Le saghe leggendarie come fonti storiche}

\author{
Hans Jacob ORNING \\ Professor of Medieval History, University of Oslo \\ h.j.orning@iakh.uio.no
}

\begin{abstract}
:
This article advocates using legendary sagas as historical sources, since these texts in spite of their non-realistic content, can tell historians a lot about the context in which the stories were written, and hence about the conditions that the people listening to them lived under. Using legendary sagas this way presupposes that they are read in their manuscript context, in line with the methodology of New Philology. However, this approach also brings along several challenges, some of which are addressed in this article. One practical challenge is to situating the manuscript historically, but in this field paleographists have done extensive work. Second, sagas are normally contained in manuscripts containing numerous sagas. This article argues that sagas should not be isolated from their manuscript context, and that manuscripts should be interpreted as totalities, not as random collections of sagas. Finally, legendary sagas deal with adventurous, allegedly "unhistorical", events. Yet, using the handling of these themes as keys to mentalities can open up new venues for historians, provided that they abandon a narrow definition of what should be considered "historical".
\end{abstract}

Keywords: legendary sagas, New Philology, mentality, manuscripts, late medieval Iceland

Résumé:

Cet article préconise l'utilisation des sagas légendaires comme sources historiques, puisqu'elles donnent aux historiens, en dépit de leur contenu peu réaliste, de nombreuses informations sur le contexte dans lequel elles ont été écrites et donc sur les conditions de vie de ceux qui les écoutaient. L'utilisation de ces sagas suppose qu'elles sont lues en lien avec les méthodes de la Nouvelle philologie. Cependant, cette approche soulève également plusieurs défis, dont certains sont abordés dans cet article. Un premier défi est de dater historiquement les manuscrits, mais les paléographes ont déjà bien avancéle travail. Ensuite, les sagas légendaires se trouvent dans les manuscrits aux côtés de nombreuses autres sagas. L'auteur soutient que les sagas ne doivent pas être isolées de leur contexte manuscrit, et que les manuscrits doivent être interprétés comme des touts, pas comme des collections constituées de manière aléatoire. Enfin, les sagas, relatent des événements prétendument "non historiques». Pourtant, en considérant le traitement de ces thèmes comme des clés pour l'étude des mentalités, on peut ouvrir de nouvelles pistes pour les historiens, à condition d'abandonner une définition trop étroite de ce qui devrait être considéré comme "historique».

Mots-clés: sagas, Nouvelle philologie, mentalités, manuscrits, Islande tardomédiévale

Tabularia «Études», nº 15, 2015, p. 57-73, 14 octobre 2015 
Riassunto:

Questo articolo insiste sull'uso delle saghe leggendarie come fonti storiche, dal momento che esse possono dare allo storico, nonostante il loro contenuto poco realistico, numerose informazioni sul contesto in cui sono state scritte, e così sulle condizioni di vita di coloro che le ascoltavano. L'uso di queste saghe presuppone siano lette sulla base dei metodi della nuova filologia. Questo approccio, comunque, comporta non pochi pericoli, di cui alcuni sono trattati nell'articolo. Un primo problema è quello di datare storicamente i manoscritti, ma i paleografi sono abbastanza avanti in questo lavoro. Inoltre, le saghe leggendarie si trovano all'interno dei manoscritti insieme a numerose altre saghe. Secondo l'autore allora le saghe non devono essere isolate dal loro contesto manoscritto, e i manoscritti devono essere trattati come delle unità, non già insomma come delle sillogi costituitesi in maniera del tutto casuale. Infine, le saghe raccontano avvenimenti presupposti "non storici». Allora, volendo considerare il trattamento di questi temi come chiave per lo studio della mentalità, è possibile aprire nuove piste davanti allo storico, a condizione appunto di abbandonare una definizione troppo stretta di ciò che può essere considerato come «storico».

Parole chiave: saghe, nuova filologia, mentalità, manoscritti, Islanda tardomedievale

In the last decades, increased attention has been devoted to saga genres such as riddarasögur (translated chivalric sagas), fornaldarsögur (legendary sagas) and fornsögur suðrlanda (indigenous romances). This probably owes something to changing literary tastes. Recently, the dominance of the realistic idiom within literary history has waned in favour of an appreciation of fantastic, non-realistic genres. The scholarly revival of these genres can furthermore be connected to the emergence of New Philology in the 1990s. This perspective directed focus at differing saga versions and the process of transmission of manuscripts as interesting topics, not as signs of decay and corruption from alleged "archetypes", as has normally been the case in traditional philology ${ }^{1}$.

These new tendencies within philology have hardly affected the historians, however, who still tend to look with suspicion on legendary sagas and normally build their investigations on "archetypes". Until the late $19^{\text {th }}$ century, legendary sagas were used by historians as reliable accounts to the past which they tell about, and since the "source critical turn" around the turn of the $2 \mathrm{O}^{\text {th }}$ century these sagas have been in a deadlock ${ }^{2}$. My aim is to alleviate this mixture of ignorance and scepticism on the part of the historians by arguing that a new philological approach resembles the tendency of historians to use sagas as evidence of mentalities and world views. Both methods take concrete

1. Haugen, 2000; Driscoll, 2010. Yet, a new philological perspective does not rule out traditional philological methods, but rather opts for an enhanced sensitivity for how sagas develop and change from manuscript to manuscript. In line with this, an alternative terminology has been suggested in order to avoid lumping too much together in the elusive term saga. An (ideal) text work consists of several (concrete) text witnesses. They are contained in manuscripts or "text bearers", the physical manuscript in which the text witness materialises. See WENDT, 2006.

2. Apart from some historians of religion and archaeologists, few scholars use fornaldarsögur as historical sources nowadays. The historian of religion Jens Peter Schjødt, for example, argues that legendary sagas can contain traces of pagan religion (SCHJøDT, 2009). 
manuscripts as their point of departure, and both are interested in investigating their broader contexts - literary or historical. In this way, the new philological approach gives the historian an opportunity to cooperate with philologists on a more equal basis. Approaching legendary sagas as sources to the historical situation in which they were written implies a departure from two common concepts/methods normally endorsed among historians: sagas and genres. The focus on specific versions of sagas in individual manuscripts means that a saga cannot be viewed as a separate entity, but rather as part of a whole, namely a manuscript (normally containing more than one saga). Second, since the labels fornaldarsögur and fornsögur suðrlanda are modern inventions, and the sagas in question appear in different manuscripts without any order reflecting these perceived generic distinctions, focus can be put on the sagas in their manuscript contexts rather than on the genres to which they allegedly belong ${ }^{3}$.

The shift of attention from archetypes to manuscripts coincides with a shift of focus from high medieval Norway and Iceland to late medieval Iceland, where most of the vellum manuscripts were produced. Traditionally this period has been viewed as one of decay both historically and literally. Iceland lost its independence, and many scholars have stated or implied that it thereby also lost its literary vigour, and that its inhabitants retreated into the realm of the fantastic for consolation in light of the harsh and unbearable realities ${ }^{4}$. This perspective contains a heavy bias in favour of the modern predilections of literary realism and originality, and a concomitant condemnation of fantasy and derivativeness. If we instead choose to work from what we know for certain, namely the extent of literary production, and try to avoid being guided by modern literary tastes, the late Middle Ages appears as the real golden age of Icelandic saga production ${ }^{5}$. Moreover, if we let the modern idea of national sovereignty go, Iceland in the late Middle Ages emerges as a prosperous region, endorsed by plenty of fish, and situated in midst of an economic rivalry between English and Hanseatic merchants, which in the $15^{\text {th }}$ century resulted in an economic boom only to be superseded in modern times ${ }^{6}$.

In this article, I shall discuss philological and historical challenges in using saga manuscripts as sources. This will be illustrated by looking at manuscripts written at the farm Möðruvellir fram ${ }^{7}$ in Eyjafjörðr in northern Iceland in the period 1450-1475. Particular emphasis will be placed on the

3. On the debate, see DrisCOLL, 2005.

4. Typical is the verdict passed by Finnur Jónsson, who in his literary history hardly commented on fornsögur suðrlanda, because they attested to the backwardness of the Icelanders: "that this could be found amusing at all, can only be explained from the cultural level of people and their isolated lives" ["at den slags overhovedet kunde more, forstås ud fra det kulturstandpunkt, man stod på og det isolerede liv, man førte $i$ det hele"] (Jónsson, 1924, p. 100, my translation). This view can also be found in more recent research, see PÁLsson, 1968, p. 14. For a different opinion on this, see Mitchell, 1991, p. 114-32.

5. Hughes, 2005, p. 219.

6. PORSTEINSSON, 1970.

7. "Modruvellir fram" is the name of the farm. 'Fram' means the one in front (contrary to the one further behind). 
manuscript AM 343a 4to, which is the largest Icelandic manuscript from the Middle Ages and contains texts of 15 sagas: nine so-called fornaldarsögur (legendary sagas), five fornsögur suðrlanda (romances) and one avintyri (moral fable $)^{8}$.

\section{The diachronic and synchronic methods}

There are two principal ways of investigating a saga from a new philological perspective: a diachronic and a synchronic one. Let's review them in turn. Most sagas are preserved in more than one manuscript. Many of them, in particular fornaldarsögur and fornsögur suðrlanda, were immensely popular and can be found in large numbers of manuscripts, in some cases 50 or more 9 . The texts preserved in these manuscripts often show considerable variation. Örvar-Odds saga is a prime example. The "age" of the saga has been widely disputed, ranging from early to late $13^{\text {th }}$ century based on internal references in the text ${ }^{10}$. However, the oldest extant manuscript of the saga is from the early $14^{\text {th }}$ century (Holm perg. 74 to). It is also found in the manuscripts AM 343a 4to and AM 471 to from the middle of the $15^{\text {th }}$ century (as well as in other manuscripts). While the two latter versions are very similar, they differ radically from the early one. This has repercussions for how we interpret the "message" of the saga ${ }^{11}$. Sometimes such changes can be so thorough within a saga that the question arises as to whether it is reasonable to classify the differing versions as belonging to the same saga, or as two different sagas ${ }^{12}$.

Changes between different versions of the same saga are particularly interesting to notice, because there must presumably have been a reason for changing the text. Instances where the text is transmitted without any significant changes are also interesting, since they testify to a continuous actuality of the passage in question. One potential objection to this might be that scribes copied texts slavishly without any concern for the content. Yet this is hardly applicable to medieval scribes writing in the vernacular. Their chief concern was to render

8. AM 343 a 4 to contains texts of the following sagas: Porsteins páttr bojarmagns, Samsons saga fagra, Egils saga einhenda ok Ásmundar berserkjabana, Flóress saga konungs ok sona hans, Vilhjálms saga sjóðs, Yngvars saga víðförla, Ketils saga hœengs, Gríms saga loðinkinna, Örvar-Odds saga, Áns saga bogsveigis, Sáluss saga ok Nikanórs, Hálfdanar saga Eysteinssonar, Herrauðs saga ok Bósa, Vilmundar saga viðutan and Perus saga meistara.

9. DRISCOLL, 2003, p. 258.

10. Örvar-Odds saga is referred to in Hervarar saga and the plot in Gesta Danorum. Lars Lönnroth believes the verses in the saga to be far older than the prose (LönnRoTH, 1979, p. 99). Torfi Tulinius (2002) has proposed the most radical redating of the legendary sagas, arguing that they were written from the late $12^{\text {th }}$ century on.

11. See Orning, 2012a for an analysis of these changes.

12. Such is the case with Tristrams saga, which was allegedly translated into Old Norse in 1226, and rewritten in Iceland in the $14^{\text {th }}$ century (preserved in $15^{\text {th }}$ century manuscripts). Here the changes in style and content are so pervasive that scholars have disagreed on whether the Icelandic version is a retelling of the previous story or a new version altogether (see ScHACH, 1961). I analyze the two different versions/texts in ORNING, 2012b. 
the text intelligible to their audience, and this implied that passages which had lost their meaning could be omitted, altered or abridged, whereas highly relevant themes could be elaborated and expanded ${ }^{13}$. Hence, a medieval text can be viewed as a mediated result of the work (transmitted through previous text witnesses, one or several of which the scribe had at his disposal, written or orally), and the scribe's own interpretation based on his own world view.

A second way of applying insights from the New Philology to manuscripts is synchronic. Here the focus is not on how one saga evolves over time, but rather on how sagas are put together in manuscripts. Traditionally philologists and historians have focused on separate sagas, studying their development or historical content respectively. But a saga seldom stands alone. Normally it forms part of a larger manuscript, and if we are to interpret a text in context, it would be misleading to view it independently of this immediate textual context. To take Örvar-Odds saga as an example once more, in the early $14^{\text {th }}$ century manuscript Holm perg. 74 to it is followed by (a fragment of) Egils saga Skalla-Grimssonar. In the $15^{\text {th }}$ century manuscript AM 343a 4to, on the other hand, it precedes Áns saga bogsveigis, and in AM 471 to Viktors saga ok Blávus. This carries implications for how we interpret the saga. In the first instance, Örvar-Oddr is succeeded by Egill, the ultimate Icelandic hero, a man who denounced kings and manifested his personal independence to his dying day. Ánn bogsveigir also opposed kings, but contrary to Egill, the king emerged victorious in his saga (although the story is more complicated and ambiguous). Viktor and Blávus, by contrast, were Vikings who became kings themselves. Thus, the larger context in which Örvar-Odds saga is situated varies greatly, and this has repercussions on how we interpret the saga. This means that even the very similar versions of Örvar-Odds saga in $\mathrm{AM}_{343 \mathrm{a}} 4$ to and AM 471 4to must be viewed as different due to their differing manuscript contexts. This brief example only concerns the adjacent sagas. A synchronic analysis must take all texts belonging to a manuscript into account.

A final context in which to situate a saga is the broader environment where a manuscript was produced. Just as separate sagas were not produced in a vacuum, manuscripts must also be analysed as part of a larger context. For a few manuscripts, like Hauksbók and Flateyjarbók, the historical context can be specified with great certainty, but normally we do not know who produced a manuscript, when and where it was produced, and for whom it was intended. Nevertheless, palaeographers and philologists have done extensive research on scribal hands and word forms that allows for cautious inferences. AM 343a 4to was probably written at the farm Möðruvellir fram in Eyjafjörðr in northern Iceland in the third quarter of the $15^{\text {th }}$ century, and Stefán Karlsson and Christopher Sanders have identified several other manuscripts from this farm. First, scribal hands can

13. Jon Gunnar Jørgensen draws attention the difference between medieval and post-medieval scribes. In the $17^{\text {th }}$ century, scribes worked in professional offices under the tutelage of antiquarians eager to transmit past texts as faithfully as possible, in a situation not very dissimilar from the one facing modern editors and translators. This contrasts with medieval scribes, who were more like artists (JørGensen, 1998, p. 92-94). 
be identified as similar to diplomas written there. Second, names figuring in the manuscripts can be connected to the same family for many generations. Thirdly, Möðruvellir fram was a farm capable in resources of producing manuscripts ${ }^{14}$. The head of Möðruvellir fram in this period was the widow Margrét Vigfúsdóttir. She must have been a devoted patron of literature, as eight other manuscripts can be attributed to Möðruvellir fram in her time, including kings' sagas, laws and Icelandic family sagas. This makes this farm one of the main literary centres of Iceland in its day ${ }^{15}$. Hence, it is possible to situate AM 343a 4to within a larger literary context, which can also be specified historically. Let's first look at the historical context, before turning to the literary one.

\section{The historical context}

Margrét Vigfúsdóttir was the owner of Möðruvellir fram in the period when AM 343a 4to is thought to have been written, and hence its probable patron. She was born in 1406 into one of Iceland's leading families and died in 1486. Both her grandfather, Ívar, and father, Vigfús, served as hirðstjóri (retinue leader, in practice head of Iceland) ${ }^{16}$. In 1397 her father married the Norwegian woman Guðridr from the Talgje family, which may have roots going back to King Håkon Håkonsson ${ }^{17}$. Vigfús's son, Ívar hólmr, took over his father's position ${ }^{18}$, but in 1433 he was killed in a fire. According to the later Gottskálks annall, the responsibility lay with Bishop Jón Gerreksson, whose allegedly illegitimate son had proposed to Ívar's sister Margrét, and as a revenge for her rejection he tried to burn them in. Margrét escaped, and promised to marry the man who avenged the misdeed. The task fell on Porvarðr Loftsson, who drowned Bishop Jón in the river Brúará and married Margrét ${ }^{19}$. Porvarðr and Margrét settled at Möðruvellir fram, which formed part of Porvarðr's patrimony. Porvarðr died only ten years after their marriage, in 1446. For the next 40 years Margrét remained a widow at Möðruvellir fram.

Margrét and her family were deeply involved in Icelandic politics of their day, and had to handle conflicts involving the king, Englishmen and the Church. As a nine-year-old girl, she sailed to England with her family under unclear circumstances, possibly because Vigfús had lost his office due to granting improper

14. SANDERS, 2000; KARLSSON, 2001.

15. The following manuscripts are thought to have been written at Möðruvellir fram: Holm perg. 7 fol., AM 81a fol. and AM 243a fol., AM 132 4to, AM 579 4to (only in fragments), AM 445c II 4to, AM 162 A 7 fol. (only in fragments), AM 673a III 4to and AM 343a 4to. See Holm-Olsen, 1986; KARLSSON, 2001.

16. Ívar hólmr Vigfússon became hirðstjóri in 1354 (Isl. Ann., 276, 356). He also figured as nuntius, collector of papal revenues in Iceland (Isl. Ann., 227). His son Vigfús was appointed hirðstjóri by Queen Margrete in 1389 (Isl. Ann., 284), and also served as nuntius (DI III, 563).

17. On the differing opinions on this issue, see LøBERG, 2000.

18. DI IV, 506.

19. Isl. Ann., 370. The story smacks of legend and story-telling, and it was surely embellished before it was put into writing more than a century later, but SIGURJónSSON (1975, p. 93-101) considers it to contain an historical core, a view which has been supported by other historians. 
favours to English merchants ${ }^{20}$. However, Vigfús' son Ívar was given high royal offices, implying that grudges cannot have been so profound. The relationship to the English also varied. Whereas Margrét's father was accused of having too close a relation to them, her family mobilised when the chieftain Björn Porleifsson was killed by the English in $1467^{21}$. Margrét's family also had conflicts with the church, as in connection with Jón Gerreksson, but here again the fronts were not stable ${ }^{22}$.

Nevertheless, the all-pervasive rivalry in Iceland in Margrét's time was not related to kings, bishops or Englishmen, but went along the lines of noble families. Around 1400 three families dominated Icelandic politics: Margrét's family (Vigfús), Loftr Guttormsson with a centre at Skarð (the Skarðverjar), and Björn Einarsson in Vatnsfjörðr, whose daughter Kristín married Porleifr Arnason (the Kolbeinsstaðamenn $)^{23}$. A concrete expression of this dominance can be viewed in the intermarriages between these families, in particular the two latter ones, who were endowed with more surviving offspring than Vigfús's ${ }^{24}$. These families were interconnected in what could be called a noble community ${ }^{25}$. As far as we know, Margrét was not directly involved in the political struggles taking place in northern and western Iceland, but with her background and as the spouse of one of Iceland's mightiest men, she was deemed to have a central position in politics ${ }^{26}$. This is not the place to discuss the political struggles between these families ${ }^{27}$. It should be sufficient to mention that an analysis of contemporary politics provides one key for understanding the manuscripts produced at Möðruvellir fram in this period.

\section{The literary context}

"It could be thought that the local aristocracy of the period had a keen sense of its own identity which it sought to manifest and strengthen through the production of manuscripts" 28 . These are Christopher Sanders's final - and rather modest - words in his facsimile edition of Holm perg. 7 fol., a manuscript which

20. The annals state that Vigfús sailed to England with some English ships which had raided the coast of Iceland (Isl. Ann., 290, 292). His widow had to answer to the king for property which her husband had forfeited (DI IV, 344).

21. PORSTEINSSON, 1970, p. 204-12.

22. Margrét herself donated lavish gifts to the churches in her surroundings during her lifetime (DI V, 233-314), and her father-in-law Loftr was a close friend of the bishop of Hólar (SigurJónsson, 1975, p. 93).

23. WæRDAHL, 2006, p. 240.

24. Out of Loftr and Porleifr's numerous children (eight and seven respectively), four were married to members of the other family (Sigurjónsson, 1975, p. 52-57). The reduction of Margrét's family to second fiddle in this struggle undoubtedly owes to Vigfús's lack of surviving offspring compared to the Skarðverjar and Kolbeinsstaðamenn. Out of eight children, only three survived childhood: Îvar, Margrét and Hólmfriðr. The latter married in Norway, and when Ívar suffered an early death, much of the initiative of this family faded.

25. SIGRIĐUR, 2011.

26. We catch a glimpse of this when her nephew and foster-son Bjarni became embroiled in conflicts between leading magnates. See SigurJónsSON, 1975, p. 136.

27. I am writing a monograph on this topic, expected to be published in 2016.

28. SANDERS, 2000, p. 52. 
he identifies as part of the Möðruvellir fram group, containing chivalric sagas and romances (as does the fragmentary AM 579 4to). The other manuscripts attributed to this milieu consists of kings' sagas (AM 81a fol. with Sverris saga, Böglunga sögur og Hákonar saga Hákonarsonar), Konungs skuggsiá (AM 243a fol.), Jónsbók

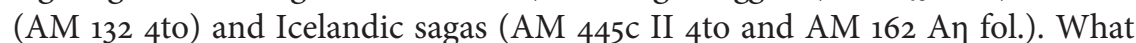
can the manuscripts produced at Möðruvellir fram tell us about what the people living there, and their probable commissioner Margrét, thought of as interesting and relevant topics of their day? The different manuscripts are characterised by a plurality of perspectives and norms, which make them unsuitable for drawing straightforward conclusions about political preferences or aims. Yet this does not imply that no lesson whatsoever can be drawn from them!

A first observation is that the king is indeed present in the mental universe at Möðruvellir fram. AM 81a fol. and AM 243a fol., containing literature for or about Norwegian kings, were probably produced and preserved together in a unity. Thus, the people at Möðruvellir fram felt themselves as part of a community with Norway. This could appear as something of a surprise, considering that Hákonar saga tells the story of how Iceland became part of the Norwegian realm. However, to an Icelandic chieftain in the $15^{\text {th }}$ century this was no story to hide or to be ashamed of. Maybe Vilhjalm of Sabina's word in 1248 that Iceland's kinglessness was improper had had its effects ${ }^{29}$ ? Moreover, Margrét herself had strong bonds to Norway. Her grandmother was Norwegian and she had a sister living there, as well as several properties. A manuscript of Jónsbók - AM 132 4to - also confirms the link between Iceland and Norway. The mental horizon in Möðruvellir fram did not stop with the Norwegian link, as three manuscripts - Holm perg. 7 fol. (three riddarasögur and eight fornsögur suðrlanda), AM 579 4to (existing only in fragments, almost identical to Holm perg. 7 fol.) and AM 343a 4to - took people farther away, to Europe, Africa and Asia.

However, acknowledging Norwegian superiority and royal ideology did not imply that Margrét and people of her standing were foreign to more "nationalistic" Icelandic literature. Among the manuscripts believed to have been produced at Möðruvellir fram is a fragment of Egils saga Skalla-Grimssonar, which originally probably contained the whole saga (AM 162 An fol.). Egils saga explained the Icelandic version of the settlement as a move away from tyrannical Norwegian kings in order to establish a society where people could govern themselves ${ }^{30}$. This highly idealised and biased story of a proud Icelandic kick-off still had its actuality, and could perfectly well co-exist with manuscripts formulating an opposite view of the ideal society. This seeming contradiction becomes smaller when we take into account that Icelandic magnates for all their scepticism towards a monarchical society were keen to establish connections with the king when it could work to their own advantage.

29. Det Arnamagnceanske Haandskrift 81a Fol., ch. 257.

30. At a local level, Svarfdoela saga (AM 445c II) tells about Icelanders settling in the localities of Eyjafjörðr in the $10^{\text {th }}$ century, thus providing the link between previous generations and the contemporary one living there. 
If one should draw a conclusion from this preliminary skimming of the manuscripts produced at Möðruvellir fram, it must be that they testify to a complex mental universe, which was wide in geographical terms and included a variety of actors: chieftains and peasants, more frequently kings and princes, in many of them giants and other fantastic creatures, whereas bishops and priests are not that common to encounter. This heterogeneity can be interpreted as a sign that there was no consensus as to what values and what traditions were considered most attractive and memorable. Yet we should not leave it at that. John Dagenais states that in the Middle Ages " $\mathrm{t}]$ exts were acts of demonstrative rhetoric that reached out and grabbed the reader, involved him or her in praise and blame, in judgments about effective and ineffective human behavior" ${ }^{31}$. If we suppose that manuscripts were utterances which reflect views of what values and norms were considered to be important, then we need to analyse the manuscripts in more detail. Here I shall limit myself to looking more closely at $\mathrm{AM}_{343 \mathrm{a}}$ 4to in order to illustrate how a manuscript can be used as a source to world views and mentalities. Using a large manuscript like AM 343a 4to as evidence of a world-view confronts us with two major challenges: a historical one concerning the gap between the saga content and the outside world, and a literary one connected to the composite nature of the manuscript.

\section{Can adventures tell us anything "real"?}

Can obviously unhistorical texts tell us anything about history - about the mentalities or conceptions of people producing or listening to them? For many scholars the answer will be negative. Legendary sagas are so purely fictional and their form and content so stereotypical that they can hardly yield information on historical issues ${ }^{32}$. However, acknowledging that a motif may be part of a common repertoire does not preclude that it can be an interesting historical topic too. Why would people be so interested in these sagas if their themes had no bearing on or relevance to their own lives?

Legends and fairytales can be used as sources for contemporary attitudes. Then the information in the sagas is not scrutinised for its factuality, but as evidence of the situation in which they were produced. In this respect, the mythical character of legendary sagas can actually be an advantage compared to the realistic idiom of kings' sagas and Icelandic sagas ${ }^{33}$. Torfi Tulinius claims that a primary function of legendary sagas was to discuss contemporary

31. Dagenais, 1994 , p. XVII.

32. A representative of this view is Axel Olrik, who established "epic laws" for how fairytales developed. (OlRIK, 1992, particularly p. 41-61). A similar view has been adopted by scholars like KALINKE, 1990 and MCKInNELL, 2005. The schematic character of legendary sagas has been underlined by Matthew Driscoll, who compares scribes to bricoleurs (DRISCOLL, 1996, p. 135; DrisCOLL, 2005, p. 197).

33. Mundal, 2003, p. 32; JaKobSSON, 2003. 
problems and complexities. Situating sagas far away in time and space did not imply removing them from contemporary issues, but conversely to provide a suitable setting for illuminating such issues without being restrained by strategic considerations.

Not only was the fornaldarsaga the one literary genre in which Icelanders' wishfulfilment fantasies were played out, it was also the one tailored precisely for the handling of vexed and hidden problems, by virtue of its long-ago, far-away, and pagan setting ${ }^{34}$.

Yet, if the mythical idiom of legendary sagas provides an advantage by camouflaging contemporary issues, by the same token it leaves us with a massive interpretative burden: How are we to interpret the stories in these sagas? Obviously, we cannot pursue a literal interpretation of the plots. Dragons, monsters and giants existed in people's imagination, but not in reality. Still, their presence can tell us something about contemporary conditions, as formulated by Margaret Clunies Ross: "The reality of the world of the gods partakes in the same metaphysical reality as that of the humans represented in non-mythical genres" ${ }^{35}$. What we have to look for are keys to interpreting the stories in the legendary sagas.

It is possible to establish some guidelines for analysing the relationship between myths and reality. First, on an analytical level one can separate between the normative and descriptive dimension of a text. Legendary sagas contain a huge amount of wish-fulfilment. Being situated in a distant past, their authors had ample opportunities to paint an image of an ideal world in which mundane frustrations were alleviated. Still, this does not exhaust the interpretative possibilities of the sagas, as they are typically filled with fights, challenges and frustrations. Even though the saga hero overcomes them all in the end, the mere amount, intensity and form of his tribulations tell us something about the problems that await anyone who wants to succeed in this world. As such, they can inform us about the types of tensions and clashes of interest underlying the story. Through careful analysis of the patterns of interaction, it is possible to arrive at a less biased, and hence less normative, level of the account. This requires a search for counter-voices in the text, which run against the explicit message and dominant morals of the story.

A second methodological issue concerns what type of events or reality legendary sagas can yield information on. It is hardly worth the attempt to use these sagas as sources to particular contemporary events. One obstacle is that we possess too little precise information about where and when manuscripts were written in order to interpret them as "keys" to events in the outside world. A more fundamental problem is that the theme of the sagas is far removed from

34. Tulinius, 2002, p. 186; Mitchell, 2011, p. 20.

35. Clunies Ross, 1994. 
contemporary realities, making attempts at drawing parallels an almost futile $\operatorname{task}^{36}$. At the other extreme, using sagas as sources to more timeless mentalities runs the risk of ignoring peculiarities within concrete manuscripts, as well as differences and tensions between them. I think we have to opt for a level in between the specific and the general. The themes have to be so specific that they allow for comparisons between different manuscripts. Manuscripts were situated in a literate field where they occupied different positions. At the same time, sagas cannot meaningfully be read as expressions of explicit political agendas. If they had had that function, there is every reason to believe that scribes would have devoted more attention to persuading and educating the reader. The best solution is to investigate topics which relate both to the themes of the text and to the tensions of the outside world, so that they can mediate the gap between text and reality without falling into one of the categories solely. Ideas about social hierarchy, magic or about the layout of the universe are examples of themes that operate at such a "middle ground".

\section{Do manuscripts have a "message"?}

The second challenge relates to how we concretely analyse manuscripts as unities. In the following I shall delineate three different ways of using saga manuscripts as historical sources. There is a hierarchy among these readings, as I shall argue that they proceed towards a progressively deeper and more nuanced understanding of contemporary conceptions. Nevertheless, all of the three interpretations provide valuable insights on their own terms.

Historians are accustomed to search for the ideological content of texts. This basically means trying to find out what message a story professes. Torfi Tulinius interprets Örvar-Odds saga as an account of a heathen warrior who ends up as a Christian king, which implies the "acceptance of a monarchicallygoverned society" ${ }^{37}$. This method of reading one or a group of sagas as a chronological account which expresses an ideological message is indeed a valid one. Then the stories of the sagas are scrutinised for their possible meanings as exemplary accounts, intended to persuade the readers of what was the right order of the world, and in how to succeed in an ideal world. With the legendary sagas this task is rendered the more feasible as the human complexities underlying the characters of the Icelandic sagas are mostly absent in these sagas. Here the heroes are heroes, and the villains are villains most of the time. No one who heard these sagas would be left in doubt about what were the right things to do.

Nevertheless, there are limitations to applying such an interpretative framework. For one thing, the ideological content does not necessarily reach

36. When for instance the depiction of females in Hrólfs saga kraka is interpreted as an expression of distrust towards Queen Margareta, this in my view entails too many uncertain factors to be defendable (JАKовsSON, 2003, p. 187).

37. Tulinius, 2002, p. 162. 
very deep into people's minds. The concept of mentality was introduced in the 1970s as a contrast to ideology in that it directs focus on aspects of human activities and thought processes which are more unconscious, collective and permanent ${ }^{38}$. Legendary sagas and romances have suffered from a bad reputation among modern scholars for being stereotypical and reinforcing the status quo. Yet the fact that these texts were highly esteemed by people for a period of several hundred years is hard to explain if all these sagas did was to uncritically celebrate dominant social values. The reason that people got something from them was that these stories allowed them to vent their frustrations, and furnished them with ideas that they found stimulating and relevant to their own lives.

A more principal shortcoming of a chronological reading relates to chronology itself, and manifests itself clearly if we proceed from single sagas to sagas as part of manuscripts. The question can be put simply: What's the story in the whole manuscript? It can be difficult to answer this question, because there is no obvious story in a manuscript such as AM 343a 4to. On the contrary, it seems to be put together rather haphazardly. Manuscripts cannot be read as consecutive stories with explicit agendas. Rather they must be viewed and analysed as entities. This implies that it is not the order of elements in a manuscript that is significant, but the totality of elements. In the case of Örvar-Odds saga, the central issue is not how the story of Oddr develops or ends, but that all his experiences constitute different aspects or possibilities within one mental universe. Hence, we should not put more emphasis on the fact that Oddr ends up as a Christian king than on his initial career as a Viking warrior. The ideals coexist, and none of them should be granted priority over the other.

The contents of a saga manuscript like $\mathrm{AM}_{343}$ 4 4 to does not fit into a neat scheme where there are no internal contradictions. Still, we should not forget that producing a manuscript was costly and time-consuming. The mere fact that there existed people who were willing to devote substantial resources to them is in itself a proof of their political relevance and power. And they did not treat them as dead relics. If there were passages they did not like or understand, they changed them. Inversely they expanded sections that they had a liking for, and they even invented plots that suited their interests. In that way, it was possible to adapt manuscripts to the needs of the time.

There are two methods for analysing manuscripts as political utterances delivered in concrete historical situations. The first mode is the structuralist one. A main goal of structuralism is to get beneath the surface of a story by uncovering its binary oppositions. According to the French anthropologist Claude Lévi-Strauss, it is a universal feature to think in terms of oppositions ${ }^{39}$. This is particularly the case with myths. Myths are structured around taboos such as incest, and play a crucial role in keeping the social fabric intact by telling what is permitted and

\footnotetext{
38. LE GOFF, 1978.

39. LÉvi-Strauss, 1972.
} 
what is forbidden ${ }^{40}$. Binary oppositions are easily applicable to legendary sagas, and can be envisioned along several axes: familiarity vs. difference, dominance vs. interaction and order vs. chaos.

For all its merits, the structuralist approach has its shortcomings and blind spots. In particular, the focus on oppositions underplays the interaction, negotiations and underlying parallels between centre and periphery. Margaret Clunies Ross has proposed a dynamic model in analysing myths, arguing that binary oppositions are not "natural", but highly disputed categories intrinsically connected to the question of power. If the periphery is populated by stupid, evil and inferior creatures, it is hard to discover any reason for interacting with it. Who is defined as in or out is a matter of definition, and the right to define is not the outcome of some arbitrary process but of power struggles between different fractions of society ${ }^{41}$. A division between centre and periphery is made actively by someone for some specific purpose.

At the basis of the dynamic between centre and periphery lies the mutual need for objects belonging to the other party, and this urge often constitutes the concrete pretext for action to be released. The relationship is not a symmetric one. Myths describe the conflicts between gods/centre and giants/periphery from the perspective of the gods ${ }^{42}$. Yet the ascendancy of the gods is fragile, and conceals the fundamental reciprocity on which the relationship rests. This perspective of a veiled reciprocity between centre and periphery demonstrates that the categories and oppositions in the text cannot be taken for granted, but have to be analyzed as situated constructs aiming at upholding and cementing a status quo. This means that behind the firm borders erected in the text, we have to look for schisms, tensions and threats, for counter-voices opposing or questioning the naturalness of the described order.

\section{Conclusion}

Reading saga manuscripts as evidence of historical contexts is a demanding exercise, which is wrought with uncertainties. Saga manuscripts are difficult to date and situate historically, and the content of legendary sagas is far removed from the historical realities in which they were written. Moreover, manuscripts with mixed content are complicated to scrutinise for their "meaning" - they simply do not fit into neat schemes of authorial intentions and messages. Nevertheless, by combining the insights gained in New Philology and the history of mentalities,

40. The Russian historian Aron Gurevich analysed the mental universe of medieval Icelanders as structured around a set of oppositions: between law and chaos, society and the wild, the kin and the unrelated, the time of the ancestors and "empty" time, and so on (GurevicH, 1985). His approach was followed up by Kirsten Hastrup, who used Icelandic laws in order to uncover mythological oppositions between gods and giants, men and monsters, society and the wilderness (HASTrup, 1985).

41. Clunies Ross, 1994.

42. Ibid., p. 60-79. A similar view has been proposed by Mundal, 2000. 
I think it is possible and indeed fruitful to approach late medieval Icelandic manuscripts with legendary sagas and romances as sources that can yield much information both on contemporary issues and on development over time. From a textual point of view, manuscripts can be analysed for their meaning as a totality. Considering the substantial resources needed to produce them, it can be taken for granted that they were put together for some purpose. By looking at the totality instead of the separate parts of the manuscripts (the sagas), and at the structure more than on the specific narratives, a broader and more general meaning in the manuscript can be discovered. This implies that separate sagas are treated as integral parts of larger manuscripts. However, the same saga can also be studied in differing versions in different manuscripts. Then changes in the manuscript context, as well as in the historical one, can yield information on changing attitudes and conceptions from one manuscript to another.

Many saga manuscripts can be situated historically, thanks to the immense efforts of palaeographers and philologists to identify scribal hands. This means that they can be related to specific historical persons and milieux. By using diplomas and annals, it is possible to link the whole textual universe of the manuscript to a concrete historical situation, allowing for an exploration of world views and mentalities of specific groups of people. However, interpreting manuscripts historically confronts the researcher with a fundamental problem of translation. How can adventurous topics tell anything about historical issues at all? The short answer is that they can. This requires a thorough discussion of what should be considered wishful thinking as contrary to what thematises social tensions and frictions. Moreover, legendary sagas can hardly illuminate "hard facts" in any precise manner. At the same time, as sources to mentalities and world views, such sagas can be veritable gold mines, because their popularity must in some way indicate that they were perceived of as relevant in a contemporary historical context. It is difficult to imagine people investing substantial resources in the production of such manuscripts if they did not value them. Legendary sagas told about heroes overcoming all sorts of troubles, but this should not deter us from investigating these troubles and tribulations in more detail. By reading stories "against the grain", one can stumble into a world which is more familiar to contemporary realities than may be apparent at first sight.

\section{Primary sources}

Det Arnamagnoeanske Haandskrift 81a Fol. (Skálholtsbók yngsta), ed. A. Kjær, Oslo 1985-1987 (orig. 1919) (Hákonar saga Hákonarsonar).

Diplomatarium Norvegicum I-XXI, ed. by C. C. A. Lange et als (Kristiania/Oslo, 1849-1995).

Diplomatarium Islandicum (Îslenzkt fornbréfasafn) I-XVI, ed. by Jón Sigurðsson et als (Reykjavík: Félagsprintsmidju, 1857-1976).

Islandske Annaler indtil 1578, ed. by Gustav Storm (Kristiania: Det norske historiske kildeskriftfond 1888). 


\section{Bibliography}

Clunies Ross, Margaret, Prolonged Echoes. Old Norse Myths in Medieval Northern Society, t. I, Odense, Odense University Press (The Viking collection: Studies in northern civilization, vol. 7), 1994.

Dagenais, John, The Ethics of Reading in Manuscript Culture: Glossing the Libro de Buen Amor, Princeton (NJ), Princeton University Press, 1994, XXIII +278 p.

Driscoll, Matthew J., "The oral, the written, and the in-between: Textual instability in the post-Reformation lygisaga", Medieval insular literature between the oral and the written, II, Hildegard L.C. (ed.), Tristram, ScriptOralia, XCIX, Tübingen, 1997, p. 193-220.

Driscoll, Matthew J., The Unwashed Children of Eve: The Production, Dissemination and Reception of Popular Literature in Post-Reformation Iceland, Enfield Lock, Hisarlik Press, 1997, 356 p.

DRISCOLL, Matthew J., “Fornaldarsögur norðurlanda: The stories that wouldn't die”, in Fornaldarsagornas struktur och ideologi: Handlingar från ett symposium i Uppsala 31.8-2.9 2001, Ármann Jаковsson, Annette Lassen and Agneta Ney (eds.), Uppsala, Uppsala universitet, Institutionen för nordiska språk (Nordiska texter och undersökningar, vol. 28), 2003, p. 257-268.

Driscoll, Matthew J., "Late prose fiction (lýgisögur)", in A Companion to Old NorseIcelandic Literature and Culture, Rory MCTurk (ed.), Malden (MA), Blackwell (Blackwell Companions to Literature and Culture, vol. 31), 2005, p. 190-204.

Driscoll, Matthew J., "The words on the page: Thoughts on philology, old and new”, in Creating the Medieval Saga: Versions, Variability and Editorial Interpretations of Old Norse Saga Literature, Judy Quinn and Emily Lethbridge (eds.), Odense, Syddansk University Press (The Viking collection: Studies in northern civilization, vol. 18), 2010, p. 85-102.

Gurevich, Aron, Categories of Medieval Culture, London, Routledge \& Kegan Paul, $1985,386 \mathrm{p}$.

Hastrup, Kirsten, Culture and History in Medieval Iceland: An Anthropological Analysis of Structure and Change, Oxford, Clarendon Press, 1985, xx + $286 \mathrm{p}$.

Haugen, Odd Einar, "Fem argument mot filologien", in Den fornnordiska texten i filologisk och litteraturvetenskaplig belysning, Kristinn JóHannesson, Karl G. JohAnsson and Lars Lönnroth (eds.), Göteborg, Göteborgs Universitet, Litteraturvetenskapliga institutionen (Gothenburg Old Norse studies, vol. 2), 2000, p. 17-26.

Hughes, Shaun, "Late secular poetry", in A Compagnon to Old Norse-Icelandic Literature and Culture, Rory McTurk (ed.), Malden (MA), Blackwell (Blackwell Companions to Literature and Culture, vol. 31), 2005, p. 205-222.

JАковsson, Ármann, “Queens of terror. Perilous women in Hálfs saga and Hrólfs saga kraka”, in Fornaldarsagornas struktur och ideologi: Handlingar från ett symposium i Uppsala 31.8-2.9 2001, Ármann Jakobsson, Annette Lassen and Agneta Ney (eds.), Uppsala, Uppsala universitet, Institutionen för nordiska språk (Nordiska texter och undersökningar, vol. 28), 2003, p. 173-189. 
JАКовSson, Sverrir, "Den eksotiske fortid. Fornaldersagaernes sociale funktion", in Fornaldarsagornas struktur och ideologi: Handlingar från ett symposium i Uppsala 31.8-2.9 2001, Ármann Jakobsson, Annette Lassen and Agneta Ney (eds.), Uppsala, Uppsala universitet, Institutionen för nordiska språk (Nordiska texter och undersökningar, vol. 28), 2003, p. 221-232.

Jónsson, Finnur, Den oldnorske og oldislandske litteraturs historie, t. III, Copenhagen, Gad, 1924, 168 p.

JørGensen, Jon Gunnar, “Om verdien av sagaavskrifter fra 160o-tallet”, Collegium Medievale, 11, 1998, p. 87-104.

Kalinke, Marianne E., Bridal-quest romance in medieval Iceland, Islandica 46, Ithaca (NY), Cornell University Press (Islandica, vol. 46), 1990, XII + 223 p.

KarLsson, Stefán, “The localization and dating of medieval Icelandic manuscripts", Saga-Book, 25, 2001, p. 138-158.

Le Goff, Jacques, "Mentaliteterne, en tvetydig historia”, in Att skriva historia. Nya infallsvinklar och objekt, Jacques Le GofF, Pierre NorA and Brigitta Oden, Stockholm, Kontrakurs, 1978, p. 244-262.

Levi-Strauss, Claude, Structural Anthropology vol. 1, New York, Doubleday, 1963.

LøвerG, Lars, “Glem Torstein mita: En kildekritisk undersøkelse av baron-ætta på Talgje og dens eventuelle forbindelse med adelsætta på Aga i Ullensvang”, Norsk slektshistorisk tidsskrift, 37:3, 2000, p. 155-170.

Lönnroth, Lars, "The double scene of Arrow-Odds drinking contest", Medieval Narrative: A Symposium, Proceedings of the Third International Symposium organized by the Centre for the Study of Vernacular Literature, held at Odense University on 20-21 November 1978, Hans Bekker-Nielsen, Peter Foote, Andreas HaArder and Preben M. Sørensen (eds.), Odense, Odense University Press, 1979, p. 94-119.

MCKInNELL, John, Meeting the Other in Norse Myth and Legend, Cambridge, D.S. Brewer, 2005, IX $+291 \mathrm{p}$.

Mitchell, Stephen, Heroic Sagas and Ballads, Ithaca (NY), Cornell University Press, 1991, XIV + 239 p.

Mitchell, Stephen, Witchcraft and Magic in the Nordic Middle Ages, Philadelphia (PA), University of Pennsylvania Press, 2011, 384 p.

Mundal, Else, "Coexistence of Saami and Norse culture - reflected in and interpreted by Old Norse myths", in Old Norse Myths, Literature and Society. Proceedings of the $11^{\text {th }}$ Saga Conference, 2-7 July 2000, Sydney, Geraldine BARnES and Margaret Clunies Ross (eds.), Sydney, Centre for Medieval Studies, University of Sydney, 2000, p. 346-355.

Mundal, Else, "Fornaldersogene - vurderinga og vurderingskriteria", in Fornaldarsagornas struktur och ideologi: Handlingar från ett symposium i Uppsala 31.8-2.9 2001, Ármann Jakobsson, Annette Lassen and Agneta Ney (eds.), Uppsala, Uppsala universitet, Institutionen för nordiska språk (Nordiska texter och undersökningar, vol. 28), 2003, p. 26-35.

Olrik, Axel, Principles for Oral Narrative Research, Bloomington (IN), Indiana University Press, 1992. 
ORNING, Hans Jacob, “Örvar-Oddr og senmiddelalderens adelskultur”, in The Legendary Sagas. Origins and Development, Annette Lassen, Agneta Ney and Ármann JAKobsson (eds.), Reykjavik, University of Iceland Press, 2012a, p. 291-322.

OrNING, Hans Jacob, “Tristram: from civilizing hero to power politician”, Arthuriana 22:1, 2012b, p. 91-108.

PÁLsson, Hermann and Edwards, Paul (trad.), Gautrek's saga and Other Medieval Tales, London, New York, University of London Press, New York University Press, 1968, 156 p.

SAnders, Christopher (ed.), Tales of Knights: Perg. Fol. nr. 7 in the Royal Library, Stockholm, Copenhagen, C.A. Reitzel (Manuscripta Nordica, vol. 1), 2000, 84 p.

Sснасн, Paul, “Some observations on Tristrams saga”, Saga-Book, 15, 1961, p. 102-129.

SCHјøDT, Jens Peter, “Kan myten være virkelighed?” in Fornaldarsagaerne: Myter og virkelighed. Studier i de oldislandske fornaldarsögur Norðurlanda, Agneta NeY, Ármann Jakobsson and Annette LAssen, Copenhagen, Museum Tusculanum Press, 2009, p. 167-18o.

Sigurjónsson, Arnór, Vestfirðingasaga 1390-1540, Reykjavík, H.F. Leiftur, 1975, 497 p.

SIGRIĐUR, Beck, I kungens frånvaro. Formeringen av en isländsk aristokrati 1271-1387, Ph.D Thesis, Göteborgs Universitet, Department of Historical Studies, 2011, 272 p. (dactyl.).

Tulinius, Torfi, The Matter of the North: The Rise of Literary Fiction in ThirteenthCentury Iceland, Odense, Odense University Press (The Viking collection, vol. 13), 2002, $340 \mathrm{p}$.

Wendt, Bo, "En text är en text är en text? Om en terminologisk tredelning av textbegreppet”, Arkiv för Nordisk Filologi, 121, 2006, p. 253-274.

WærDaHL, Randi Bjørshol, Norges Konges Rike Og Hans Skattland. Kongemakt Og Statsutvikling I Den Norrøne Verden I Middelalderen, Ph.D Thesis, Norges teknisknaturvitenskapelige universitet (NTNU, Trondheim), Det historisk-filosofiske fakultet, Institutt for historie og klassiske fag, 2006, 277 p. (dactyl.).

PORsteinsson, Björn, Enska öldin í sögu Íslendinga, Reykjavík, Mál og menning, 197o, $322 \mathrm{p}$. 